\title{
Enlightenment of Jiang Hengyuan's Views on Youth in the We-Media Era
}

\author{
Fei Yin* \\ Lianyungang Normal College, Lianyungang 222000, Jiangsu Province, China \\ *Corresponding author: Fei Yin, my15010923357@163.com
}

\begin{abstract}
In the era of science and information technology, various We-Media have come into being. We-Media is becoming an important part of people's life. It directly affects people's lifestyles and mindsets, which is particularly obvious in the process of education and teaching reform in colleges. There is no doubt that college students are the impelling force behind We-Media and have made great contributions to promoting the development of We-Media in China. However, consolidated with relevant practical investigations, it has been found that in the mixed We-Media environment, improper behaviors have surfaced among students, such as internet addiction, cyberbullying, and money worship, due to various inducements, thus affecting their physical and mental health. Jiang Hengyuan, a founder of vocational education development in modern China, proposed that it is not only necessary to pay attention to the training of production professions in terms of knowledge and skills, but also to the cultivation of civic morality, service morality, and national spirit while advocating the talent training mode of "double cultivation of spirit and flesh," which points out the direction for today's youth education management.
\end{abstract}

Keywords: We-Media; Jiang Hengyuan; Youth ideological education

Publication date: October 2021; Online publication: October 29, 2021

\section{Introduction}

The We-Media era is a creative product of the network era. Under the background of the network era, the public is both the receiver and disseminator of information. For college students, personal learning and their growth environment are becoming more and more diverse, and their access to information channels is far more lavish than before. Having strong ability to embrace new things, young students are extremely active on We-Media, and almost every college student has a personal account. Compared with traditional media requiring high professionalism, We-Media, as a unique way of communication, is quite simple and flexible; it is no longer bound by time and space, consequently gaining more popularity among young people. With a mobile phone that is given access to the internet, everyone is able to express their personal views and share their daily life.

However, there are many unavoidable problems behind the rapid development of We-Media. For example, a great deal of western ideological trends represented by new liberalism have been flowing into China without meeting any resistance. Various internet celebrities have gone viral on social media; some showing off their wealth and bellies, while others yelling "yesmola" or "yuyu disease" (cyber slang for psychological depression). It seems truly challenging to effectively restrict their online behaviors. As a result, the world views, values, and outlooks on life of young college students, which are underdeveloped, have been badly influenced. Whether on the internet or in reality, these abnormal phenomena have formed an extremely vicious circle and awful influence, affecting the physical and mental health of college students. In order to ensure that the online reviews and behaviors of college students are under control, colleges should pay more attention to the cultivation of civic morality, service morality, and national spirit in ordee 
to realize students' all-round growth and development.

\section{Investigation and analysis of college students' network behaviors in the We-Media era}

In order to better understand the current behaviors of college students on We-Media, an empirical research was conducted. Lianyungang Normal College was selected to carry out an anonymous electronic questionnaire survey. A total of 1,305 valid electronic questionnaires were obtained, and the results of which to some extent revealed the dark sides of We-Media.

\subsection{Investigation on the choices of We-Media platforms among college students}

The results of the investigation showed that among QQ, WeChat, Sina Weibo, and other common social media platforms, TikTok was selected as the most popular app used among students, with an endless feed of short, light-hearted videos attracting hundreds of millions of users around the world. $88.81 \%$ of the respondents preferred TikTok, while $87.28 \%$ of them preferred QQ Space. Through data analysis, it is not difficult to find that many college students use multiple We-Media platforms at the same time, indicating the immense zeal for cyber sharing.

\subsection{Investigation on the purpose of using We-Media among college students}

The survey result showed that the purposes of using We-Media among college students are mainly for recreation $(87.66 \%)$, news $(79.39 \%)$, learning materials $(72.87 \%)$, socialize $(64.21 \%)$, shopping $(62.15 \%)$ and recording life $(60.77 \%)$. It seems that We-Media basically covers all aspects of college students' life and has become an irreplaceable tool.

\subsection{Investigation on college students' "stickiness" to We-Media}

$31.42 \%$ of the respondents spend 1-3 hours on We-Media every day, 37.09\% spend 3-5 hours, and 23.76\% spend more than 5 hours. The average time of using We-Media comes up to 3.5 hours per day, which is quite a long period. The stronger the "stickiness" of students toward We-Media, the lower their network self-discipline ability.

\subsection{Investigation on college students' immoral behaviors on the internet}

Psychological immaturity and lack of common sense are the common characteristics of modern-day college students, so they are likely to make judgments or decisions, which often turn out to be biased or incorrect, without in-depth thinking. In addition, the "virtuality" and "freedom" of the internet weaken people's sense of moral responsibility, especially when internet celebrities deliberately post extreme opinions or false reports on social issues. This is why students, with the agitation of adolescence, tend to behave more aggressive or immoral, and sometimes even participating in cyber manhunt or cyberbullying on the internet.

\section{Connotation and practical significance of Jiang Hengyuan's views on youth}

Jiang Hengyuan, who was born in Banpu Town, Guanyun County (now, Haizhou District), Lianyungang City in November 1885, was once a professor from the University of China in Beijing, President of the Eighth Normal School of Jiangsu Province (the predecessor of Lianyungang Normal College), Director of the Department of Education of Jiangsu Province, member of the Henan Provincial Government, and Director of the Department of Education. In July 1928, he was appointed as the Director of the Office Department of China Vocational Education Society in Shanghai. After the founding of new China, he successively served as a member of the Culture and Education Committee of the Central Government and 
a member of the Culture and Education Committee of East China. He was not only a representative of the educational circles at the First Plenary Session of the Chinese People's Political Consultative Conference, but also a member of the second and third CPPCC National Committee. In his later years, he returned to his hometown, served as the President of the Eighth Normal School of Jiangsu Province, and trained a large number of young students with progressive ideas.

\subsection{Historical mission of youth}

The mission that young people need to shoulder, in some sense, is the responsibility to be stronger than the preceding generation ${ }^{[1]}$. "Every generation of young people have their own opportunities and fortunes; all of them have to plan their lives and create history under the conditions of their own times ${ }^{[2]}$." The modern Chinese history was filled with struggles for survival. The historical mission of the young people in the early 20th century was to save the country and people from danger. However, the historic reality was that masses of Chinese young people were abject weak, depressed, confused, lazy, negative, stubborn, selfish, and suspicious. Under this turbulent situation, Jiang Hengyuan was concerned about the state having no talents, and the people who are in danger of lacking food. He mentioned, "We have made some observations on the current general phenomenon in China, and we deeply feel that there is an urgent need for two kinds of talents: (1) social leaders; (2) national production laborers ${ }^{[3]}$." According to further explanation, social leaders refer to those who have extraordinary achievements in various fields of social undertakings with a broad mind and universal fraternity, while national production laborers are people engaged in agriculture, industry, and commerce who have scientific labor knowledge and skills. Jiang Hengyuan believed that in order to truly solve the problem of national survival fundamentally, it is a requisite to start with education and instruct the declining productive forces in China with vocational education. "We are aware that training vocational knowledge and skills as well as enforcing national education should be recognized as the two main branches of today's Chinese vocational education; the former of which is like nutrition for the body and the latter is for cultivating the national spirit. The two branches depend on each other, just like the two wheels of a bike and the two wings of a bird. In any case, we should not neglect them ${ }^{[3]}$." On February 7, 1933, Jiang Hengyuan published a signed article, To the Youth of the Whole Country, in Shen Bao (Shanghai News), where he once again petitioned the young people to always reflect on themselves in order to stand on their own feet, since the future development of the country and nation depend on their actions. He also implored the young people not to be trapped by materials or fascinated by sexual desires but to protect their own bodies by exercising frequently and systematically. This is the minimum responsibility of young people to themselves and to the country as well ${ }^{[4]}$.

Each generation of young people has their own opportunities, and at the same time, creates their own history. In this entirely new era, contemporary Chinese youth are appointed a new mission; that is, to strive to realize the great rejuvenation of the nation under the leadership of Chinese Communist Party. Students must be acutely aware of the relationship between individuals and the country. Only when people have achieved the national ideal of nation independence, then they will have the opportunity to realize their personal ideals and create better development conditions for themselves.

At present, through We-Media and other communications, western ideological trends, such as liberalism and populism, are constantly invading and corroding the brains of the Chinese youth, leading to an upswing of money worship, hedonism, and personal extremism. Therefore, it is time for colleges to take action by strengthening the guidance of students' ideology as well as intensifying the education of patriotism, history, and China's outstanding traditional culture in order to train up young people as qualified socialist builders and successors. Cultivating national self-esteem, national cohesion, and national spirit with patriotism as the core would help the youth establish correct world views, values, and outlooks on life. It is important for young people to have the ability to develop with the times, free themselves from the 
illusory network, and realize their life values by striving.

\subsection{Three abilities of youth}

"A person who do not have self-reliance can been seen as a moth of the society, a person without selfdefense skills is a coward, and a person without the ability to self-educate is an addlehead. However, if an individual have all three abilities, that individual can save himself or herself and if the majority of people have these three abilities, they can save the country ${ }^{[5]}$." Jiang Hengyuan pointed out that young people ought to develop these three abilities. First, self-reliance - the ability to produce without asking for help from others. In this way, they can maintain the livelihood of individuals and families as well as serve the society and improve their undertakings. Second, self-defense - the ability to defend oneself and the country, which requires both a healthy physique and an indomitable spirit. Third, self-education - the ability to teach oneself to seek enlightenment.

As an old saying goes, "What is learned from books is superficial after all." However, it is crucial to put it into practice somehow. Unfortunately, many young people nowadays are becoming nerds with inadequate practical experience. The current We-Media seems like a double-edged sword, considering that it can break through the limitations of time and space with enriching information, but at the same time, it may lead to internet addiction and critical damage to health. In order to avoid that, it is necessary to adhere to the policy of combining educational activities with production and labor as well as insist on the horizontal integration of practical education, labor education, and physical education. That is the fundamental way for young people to truly realize self-reliance, self-defense, and self-education while keeping away from indulging in the virtual world.

\section{Conclusion}

Breaking the top-down communication mode of traditional media with a new way of illustrated, interactive, and real-time sharing communication, We-Media has gradually infiltrated into college students' daily lives, bringing convenience but also leaving a few tricky problems to be settled.

Jiang Hengyuan's ideology of youth education is identified as a theoretical system formed in the practice of vocational education, in which he had been engaging for his whole life. The vocational education he advocated is not restricted to training students to master skills just for a living, but educating them to acquire moral cultivation, social service spirit, national spirit, and patriotism, which are all essential for college education in the era of We-Media.

\section{Funding}

This study was supported by the 2020-2021 Lianyungang Social Science Fund Project: "Research on Jiang Hengyuan's Views on Youth and Its Enlightenment to Youth Education in Higher Vocational Colleges" (Number: 20LKT2036; Project Director: Yin Fei).

\section{Disclosure statement}

The author declares that there is no conflict of interest.

\section{References}

[1] Literature Research Office of the CPC Central Committee, 2014, Selected Works of Important Documents since the 18th National Congress (Vol. I), Central Literature Publishing House, Beijing, 278. 
[2] Literature Research Office of the CPC Central Committee, 2016, Selected Works of Important Documents since the 18th National Congress (Vol. II), Central Literature Publishing House, Beijing, 2.

[3] Jiang H, 1934, The Policy to Be Adopted in China's Education and the Standards for the Implementation of Vocational Education. Journal of Education, 24(1).

[4] Jiang H, 1933, To the Youth of the Whole Country, Shen Bao.

[5] Jiang W, 1932, Methods of Life. Education and Occupation, (132). 